\title{
Cysticercosis in experimentally and naturally infected pigs: Parasitological and immunological diagnosis ${ }^{1}$
}

\author{
Márcia R.M. da Silva ${ }^{2}$, Cibele N.S. Uyhara ${ }^{2}$, Flavio H. Silva ${ }^{3}$, Noeli M. Espindola ${ }^{4}$, \\ Mirele D. Poleti ${ }^{2}$, Adelaide J. Vaz ${ }^{4}$, Flávio V. Meirelles ${ }^{2}$ and Antonio A.M. Maia ${ }^{2^{*}}$
}

\begin{abstract}
Silva M.R.M., Uyhara C.N.S., Silva F.H., Espindola N.M., Poleti M.D., Vaz A.J., Meirelles F.V. \& Maia A.A.M. 2012. Cysticercosis in experimentally and naturally infected pigs: Parasitological and immunological diagnosis. Pesquisa Veterinária Brasileira 32(4):297-302. Departamento de Ciências Básicas, Faculdade de Zootecnia e Engenharia de Alimentos, Universidade de São Paulo, Av. Duque de Caxias Norte 225, Pirassununga, SP 13635-900, Brazil. E-mail: antomaia@usp.br.

Our objective was to evaluate the diagnosis of swine cysticercosis by examining "ante mortem" (inspection of the tongue), "post mortem" (inspection and detailed necropsy) and ELISA for research in serum of antibodies (Ab-ELISA) and antigens (Ag-ELISA). Seven (7) pigs were experimentally infected orally with eggs of Taenia solium and another 10 were naturally infected. In the pigs experimentally infected, inspection of the tongue was negative in all animals, in the routine inspection detailed necropsy and cysticercis were identified in all of them. In pigs with heavy natural infection, inspection of the tongue identified cysticerci in two (20\%), while at inspection with necropsy the parasites were identified in large quantities in all animals. In ELISA for antibody search (Ab-ELISA) TS-14 recombinant protein was used, and in search for antigen (Ag-ELISA) a monoclonal antibody against this protein. In animals experimentally infected, blood was collected weekly for 140 days. The Ab-ELISA identified an increase in titers of antibody to cysticerci 21 days after infection, and at the end of the experimental period six animals (86\%) were positive to the test. The search for circulating antigens (Ag-ELISA) was positive in two pigs 28 to 91 days after infection. All naturally infected pigs were positive for Ag-ELISA and Ab-ELISA. The search for antibodies and antigens by ELISA in serum from 30 pigs of a local farm and without history of cysticercosis was negative. Thus, the use of TS-14 antigen in ELISA test (Ab-ELISA) can be useful for the diagnosis of cysticercosis in pigs with low infection.
\end{abstract}

INDEX TERMS: Pigs, cysticercosis, diagnosis, ELISA.

RESUMO.- [Cisticercose em suínos infectados experimentalmente e naturalmente: diagnósticos parasitológico e imunológico.] Nosso objetivo foi avaliar o diagnóstico de cisticercose suína através do exame "ante mortem"

\footnotetext{
${ }^{1}$ Received on October 17, 2011.

Accepted for publication on November 26, 2011.

${ }^{2}$ Departamento de Ciências Básicas, Faculdade de Zootecnia e Engenharia de Alimentos (FZEA), Universidade de São Paulo (USP), Av. Duque de Caxias Norte 225, Pirassununga, SP 13635-900, Brazil. *Corresponding author: antomaia@usp.br

${ }^{3}$ Departamento de Genética e Evolução, Universidade Federal de São Carlos, Via Washington Luis, Km 35, Cx. Postal 676, São Carlos, SP 13565905, Brazil.

${ }^{4}$ Departamento de Análises Clínicas, Faculdade de Ciências Farmacêuticas, USP, Av. Professor Lineu Prestes 580, Bloco 17, São Paulo, SP 05508900, Brazil.
}

(inspeção da língua), "post mortem" (inspeção e necropsia detalhada) e teste de ELISA para a pesquisa no soro de anticorpos (Ab-ELISA) e antígenos (Ag -ELISA). Sete (7) suínos foram infectados experimentalmente por via oral com ovos de Taenia solium e outros 10 eram portadores de infecção natural generalizada. Nos suínos experimentalmente infectados, a inspeção da língua foi negativa em todos os animais, na inspeção 4 (57\%) estavam infectados, a necropsia detalhada identificou cisticercos em todos os animais. Nos animais com infecção natural generalizada, a inspeção da língua identificou cisticercos em 2 (20\%), enquanto que a inspeção e a necropsia os parasitas foram identificados em grande quantidade em todos os animais. No teste de ELISA para a pesquisa de anticorpos (Ab-ELISA) foi utilizada a proteína recombinante TS-14 e para a pesquisa de antíge- 
nos (Ag-ELISA) um anticorpo monoclonal produzido contra esta proteína. Nos animais experimentalmente infectados o sangue foi coletado semanalmente por um período de 140 dias. 0 Ab-ELISA identificou um aumento nos títulos de anticorpos para cisticercos 21 dias após a infecção, sendo que no final do período experimental 6 animais (86\%) foram positivos ao teste. A pesquisa de antígenos circulantes (Ag-ELISA), foi positiva em 2 animais, entre os dias 21 e 91 após a infecção . Todos os suínos com infecção natural generalizada foram positivos para Ag-ELISA e Ab-ELISA.A pesquisa de anticorpos e antígenos pelo ELISA realizada no soro de 30 suínos procedentes de uma criação local sem historia de cisticercose foi negativa. Assim o uso do antígeno TS-14 (Ac-ELISA), pode ser útil para o diagnóstico da cisticercose em suínos com baixa infecção.

TERMOS DE INDEXAÇÃO: Suínos, cisticercose, diagnóstico, ELISA.

\section{INTRODUCTION}

Taenia solium cysticercosis is one of the most serious parasitic infections in humans in developing countries of Africa, Asia and Latin America, where pork meat is often consumed and hygiene standards are low. As swine are the main intermediate hosts participating in the maintenance of the parasite in the environment, control measures for porcine cysticercosis can interrupt the parasite life cycle (Flisser et al. 2003). Moreover, porcine cysticercosis imposes a significant economic burden on individual farmers and the meat industry in endemic areas (Pawlowski et al. 2005). It is worthy of note that cases of porcine cysticercosis detected in official abattoirs represent a significant underestimation of the true prevalence of the disease in endemic countries (Pawlowski et al. 2005).

Brazil is considered an endemic area (Román et al. 2000). In surveys conducted in the state of Bahia, serum samples obtained from pigs and examined through enzyme-linked immunoelectrotransfer blot assay revealed a prevalence of cysticercosis antibodies of 4.4\% (2 of 45) in the city of Salvador, 3.2\% (3 of 93) in Santo Amaro and $23.5 \%$ (24 of 102) in Jequié (Sakai et al. 2001), confirming the severity of the problem in the country.

The diagnosis of cysticercosis in pigs can be made by in vivo tongue palpation or meat inspection, which are specific parasitological techniques, but are not very sensitive when used on pigs with a low cyst burden (Sciutto et al. 1998, Boa et al. 2002). Serological diagnosis methods are important tools for epidemiological studies, as they can be applied to living animals and on a large scale (Gonzales et al. 1990) and can help detect cysticercosis in animals with light or recent infections (Pinto et al. 2000).

Serodiagnosis of cysticercosis through the detection of antibodies against the parasite has been widely evaluated using target antigens ranging from total $T$. solium extracts of the metacestode to more selected preparations, such as cyst fluid, scolex or extracts from external membranes (Nunes et al. 2000, Nguekam et al. 2003, Soares et al. 2006). Other detection methods include highly purified or fractionated parasite glycoproteins (Tsang et al. 1991, Aluja et al. 1999) or recombinant and synthetic antigens (Sato et al.
2003, Handali et al. 2004, Silva et al. 2006), which increase the sensitivity and the specificity of the tests. The use of DNA recombinant technology permits the obtainment of high amounts of purified proteins, enabling the development of more sensitive and specific assays. However, a number of studies have reported poor antigenicity for antigens lacking glycosylation (Obregon-Henao et al. 2001). Among the native antigens analyzed, the $14 \mathrm{kDa}$ protein isolated from T. solium cysticerci is considered one of the most promising proteins (Tsang et al. 1991, Greene et al. 2000, Obregon-Henao et al. 2001, Assana et al. 2007).

Antibody detection (Ab-ELISA) may indicate exposure to infection and not necessarily the presence of an established viable infection, resulting in transient antibodies (Garcia et al. 2001). The identification of pigs infected with viable larvae is achieved through the detection of secreted products of viable parasites (Ag-ELISA). Promising results have been obtained using monoclonal antibodies (MoAb) for the detection of circulating excretory-secretory products in T. solium cysticercosis (Sciutto et al. 1998, Dorny et al. 2003, Dorny et al. 2004). In experimentally infected pigs, circulating antigens were first detected between two and six weeks after infection even in pigs carrying only five to eight living cysts (Niguekam et al. 2003).

A previous study by our group (Silva et al. 2006) found that the use of TS14 for the detection of anti-cysticercus antibodies in cerebral fluid and serum samples from human patients in Brazil was efficient, demonstrating high sensitivity and specificity.We report here the fisrt time the application of TS14 recombinant antigen and the monoclonal antibody against this protein in the immunodiagnosis of porcine cysticercosis.

\section{MATERIALS AND METHODS}

Experimental infection. Taenia solium eggs were obtained from a patient after treatment with niclosamide. The parasites were recovered from the feces and T. solium was identified on the basis of segment morphology. The eggs were isolated from gravid segments and stored at $4^{\circ} \mathrm{C}$ during 28 days (Lightowlers et al. 1996). Seven 2-month-old landrace piglets from an intensive pig farm were orally infected with 200,000 eggs. Feed and water intake were controlled during the experiment to avoid possible contamination.

Serum samples of pigs. Blood samples from all pigs were obtained by intravenous puncture before infection as well as every week of the experimental period (140 days). Ten serum samples were obtained from naturally heavily infected pigs confirmed by necropsy. The negative control group was composed of 30 serum samples from pigs at a local farm with good hygienic conditions and no history of cysticercosis.

Parasitological methods. The presence of cysticerci was evaluated through examination of the tongue, following by routine meat inspection and detailed necropsy. Tongue inspection was performed before slaughter and the animals were considered positive for cysticercosis if cyst-like nodules were either seen or felt (Gonzalez et al. 1990). All experimentally infected pigs were slaughtered (140 days after infection) and routine meat inspection was performed to determine the presence of cysticerci in predilection sites: masseter muscle, heart and tongue (Boa et al. 2002). The inspection was carried out through visual examination and incisions in the muscles and organs. Detailed necropsy was 
then performed only on the experimentally infected pigs, from which the entire musculature and organs were cut into thin slices of about $0.5 \mathrm{~cm}$ (Boa et al. 2002). The cysticerci were classified as vesicular and non-vesicular based on their macroscopic appearance (Phiri et al. 2006).

Preparation of TS14 recombinant antigen. T. solium cysticerci were obtained from the muscles of naturally infected pigs from São João da Ponte (state of Minas Gerais, Brazil). The TS14 cDNA containing an open reading frame with 258 nucleotides, which encodes an 86-amino acid polypeptide, was obtained through RT-PCR from T. solium cysticerci total RNA and subcloned into a pET28a(+) (Novagen, Madison, WI) expression vector, which was used to transform E. coli BL21 (DE3) cells for the production of the TS14 protein. The generated protein was purified in a Ni-NTA (Quiagen, Valencia, CA) affinity column (Silva et al. 2006).

Preparation of Monoclonal antibody (MoAb) against TS14. Balb/c mice were immunized with purified TS14 recombinant antigen and monoclonal antibodies (MoAb) were obtained as described by Espíndola et al. (2002). MoAb isotypes were determined using a commercial kit (Mouse monoclonal antibody isotyping reagents, Sigma).

Utilization of TS14 antigen for detection of antibodies (Ab-ELISA). The ELISA test was performed as described by Pinto et al. (2000), with some modifications. The optimal dilutions of antigens, test serum samples and conjugate were determined through checkerboard titration. The 96-well plates (Costar, Corning, USA) were sensitized with $100 \mu \mathrm{L} /$ well of TS14 antigen $(0.1 \mu \mathrm{g} /$ well $)$ diluted in $0.5 \mathrm{M}$ carbonate-bicarbonate buffer at $\mathrm{pH} 9.6$ for $1 \mathrm{~h}$ at room temperature and later at $4^{\circ} \mathrm{C}$ for $14 \mathrm{~h}$. Wells were blocked for $1 \mathrm{~h}$ with $5 \%$ skimmed milk in phosphate-buffered saline (PBS; 0.01M; pH 7.2; $0.0075 \mathrm{M} \mathrm{Na}_{2} \mathrm{HPO}_{4}, 0.025$ $\mathrm{M} \mathrm{NaH} \mathrm{PO}_{4}, 0.15 \mathrm{M} \mathrm{NaCl}$ ) containing $0.05 \%$ Tween 20 (PBS/T) and incubated for $1 \mathrm{~h}$ with the sera diluted 1:100 in 1\% skimmed milk in PBS/T. Rabbit anti-pig-IgG peroxidase-conjugate (Sigma Chem. Co., St Louis, MO.) diluted 1:100,000 in 1\% skimmed milk in PBS/T was added and the plates were incubated for $1 \mathrm{~h}$. After each incubation step, the plates were washed using an automatic washer, with six cycles of PBS/T. A commercial mix of tetramethylbenzidine and $\mathrm{H}_{2} \mathrm{O}_{2}$ (Sigma) was used as the chromogenic substrate for $8 \mathrm{~min}$. The reactions were stopped by adding $100 \mu \mathrm{l}$ of $2 \mathrm{M} \mathrm{H}_{2} \mathrm{SO}_{4}$ Color intensity was quantified using an ELISA plate reader (Labsystems Multiskan, Finland) at $450 \mathrm{~nm}$. All incubations were carried out at $37^{\circ} \mathrm{C}$.

Use of MoAb-TS14 for the detection of circulating antigen (Ag-ELISA). The Ag-ELISA was performed as described by Dorny et al. (2002), with minor modifications. Serum samples were pre-treated with 5\% trichloroacetic acid (Dorny et al. 2000, Nguekam et al. 2003) and incubated for $20 \mathrm{~min}$ at room temperature to dissociate immune-complexes. After 5 minutes of centrifugation $(10000 \mathrm{~g})$, the supernatant was neutralized using the same volume of a 0.6 M sodium carbonate/ bicarbonate buffer ( $\mathrm{pH} 9.6$ ). Each well of 96-ELISA polystyrene plates (Costar Corning-high bind, USA) was coated with anti-TS14 monoclonal antibody (1.6 $\mathrm{mg} / \mathrm{mL}$ ) diluted 1:100 in PBS buffer ( $\mathrm{pH} 7.2)$. Coated plates were incubated in a humidified chamber at $37^{\circ} \mathrm{C}$ for 2 hours and then at 4 o $\mathrm{C}$ overnight. The wells were blocked with $200 \mu \mathrm{l}$ of $5 \%$ skimmed milk in PBS-T (0.05\% tween 20 and $1 \%$ skimmed milk) and the plates were incubated again at $37^{\circ} \mathrm{C}$ for 1 hour. Sera pre-treated with TCA were incubated overnight with biotinylated Moab-TS14 in PBS-T (1:62.5) at $4^{\circ} \mathrm{C}$ and $100 \mu \mathrm{l}$ added to each well. The plates were incubated at $37^{\circ} \mathrm{C}$ for 5 hours and washed six times with $250 \mu \mathrm{l}$ of PBS-T. Conjugate avidin peroxidase (Sigma Chem. Co; USA) diluted 1:10000 $(100 \mu \mathrm{l})$ was added per well and the plates were incubated for 1 hour at $37^{\circ} \mathrm{C}$. After washing six times with PBS-T, $100 \mu \mathrm{l}$ of TMB chromogen substrate (Sigma) was ad- ded per well and the plates were maintained at room temperature for 15 minutes. The reaction was stopped by adding $100 \mu \mathrm{l}$ of $2 \mathrm{~N}$ sulfuric acid. The plates were read at $450 \mathrm{~nm}$ with the Labsystems Multiskan Reader.

Determination of cut off values. Each unknown sample was tested in duplicate. Mean absorbance was determined and compared with the cut off value. A blank (assay without sample) was also included in each plate. The assay was monitored by including standards in each plate, chosen among the positive and negative samples. The cut off was calculated as the mean optical density (OD) of the 30 samples from the negative control group plus 2 SD.

Ethics Committee Approval. The experiment received approval from the ethics committee for animal research of the Faculty of Animal Science and Food Engineering - FZEA/USP, project 29/2008.

\section{Parasitological results}

\section{RESULTS}

The tongue examination was unable to detect cysticerci in the experimentally infected pigs. Routine meat inspection and detailed necropsy revealed that the infection was light. Parasites were identified in $57 \%$ and $100 \%$ of the pigs after routine meat inspection and detailed necropsy, respectively (Tab.1). The Infection was highly variable among the organs and muscle groups. Only vesicular cysts (238 viable cysts) were observed, with the number per animal ranging from 1 to 85 , in the heart (8.4\%), tongue (3.78\%), masseter (5.88\%) and other skeletal muscles (81.93\%).

Detailed necropsy was not performed on the naturally heavily infected pigs, and innumerous cysts were found in the predilection sites (heart, diaphragm, tongue) as well as all skeletal muscles. Tongue inspection and routine meat inspection were positive in $\%$ and $100 \%$ of the animals, respectively (Table 1).

Table 1. Cysticercosis in experimentally and naturally heavily infected pigs assessed by parasitological exams and serological tests

\begin{tabular}{lccccc}
\hline \multicolumn{1}{c}{ Pigs } & $\begin{array}{c}\text { Tongue } \\
\text { examination } \\
(\%)\end{array}$ & $\begin{array}{c}\text { Routine } \\
\text { inspection } \\
(\%)\end{array}$ & $\begin{array}{c}\text { Detailed } \\
\text { necropsy } \\
(\%)\end{array}$ & $\begin{array}{c}\text { Ag-ELISA } \\
(\%)\end{array}$ & $\begin{array}{c}\text { Ab-ELISA } \\
(\%)\end{array}$ \\
\hline $\begin{array}{l}\text { Experimentally } \\
\text { infected (n=7) }\end{array}$ & 0 & 57 & 100 & 29 & 86 \\
$\begin{array}{c}\text { Naturally heavily infected } \\
(\mathrm{n}=10)\end{array}$ & 20 & 100 & $*$ & 100 & 100 \\
\hline (n) & & & & &
\end{tabular}

* Exam not performed.

\section{Detection of antibodies using Ab-ELISA}

Figure 1 displays the kinetics of the antibody levels in the experimentally infected pigs. Antibody levels increased at 21 days post infection (PI) in the majority of experimentally infected animals, with a fluctuation in levels throughout the experiment. Six of the seven pigs (86\%) were positive at the end of the test ( 140 days PI). No correlation was found between the number of cysts and antibody response. No positive results were observed in the sera from the negative control group. All serum samples from the naturally heavily infected pigs were positive for antibodies against the TS14 antigen, based on a cut-off value of 0.388 .

\section{Detection of circulating antigen using Ag-ELISA}

Circulating antigens were detected in only two of the experimentally infected pigs, with 60 and 85 cysts, betwe- 
en 21 and 91 days PI. The antigen level was substantially lower in comparison to the naturally heavily infected pigs. The other pigs remained serum negative throughout the experimental period. All serum samples from naturally heavily infected pigs (10) were positive for Ag-ELISA based on a cut-off value of 0.363 . No positive results were observed in the sera from the negative control group (Fig.2).

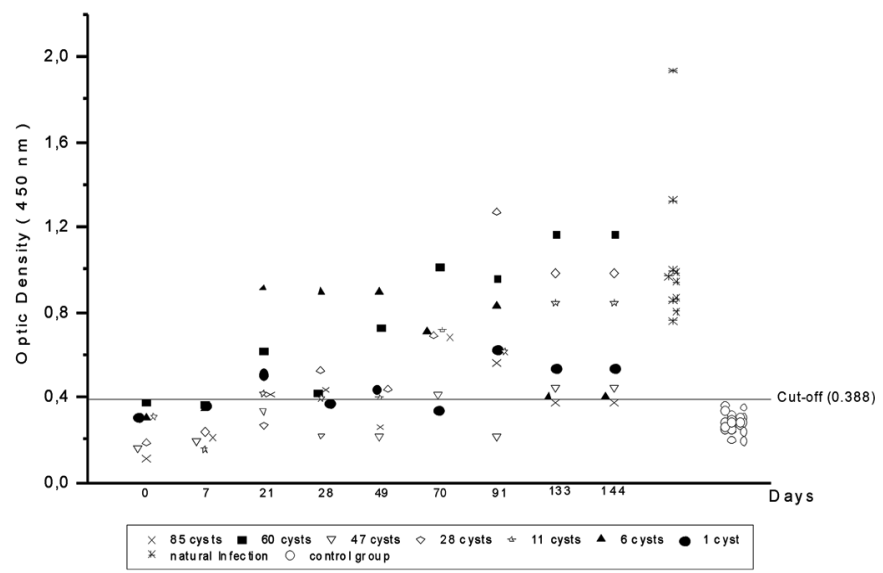

Fig.1. ELISA results expressed as OD using TS14 antigen for detection of antibodies in serum samples from pigs experimentally and naturally infected by Taenia solium cysticerci

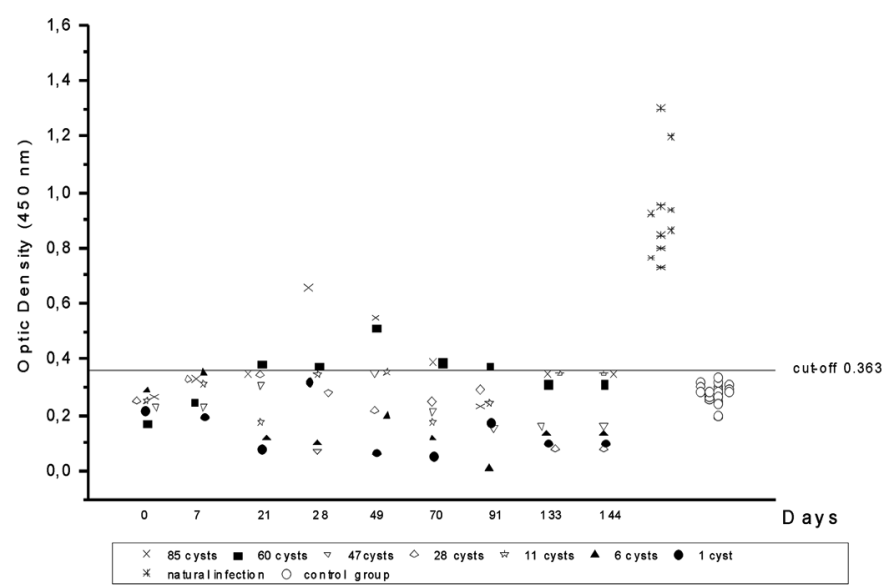

Fig. 2. ELISA results expressed as OD, using MoAb-TS14 for detection of circulating antigens in serum samples from pigs experimentally and naturally infected by Taenia solium cysticerci

\section{DISCUSSION}

The results demonstrate that piglets infected at the same young age, through the same pathway and with the same number of parasites reacted differently; thereby confirming that efficiency of the establishment of cysts differs among animals, as previously reported (Aluja et al. 1996). Considering the number of eggs administered, the parasitism rate was low (mean value of $0.17^{\circ} / 00$ ), ranging from 1 to 85 cysts per animal. The low cyst recovery rates may be attributed to either the immune response of the host or the viability of the eggs. No egg viability test was performed in the present study and the long storage time may have been the cause of lower infectivity. However, a number of studies have found that T. solium eggs maintain infectivity even at a temperature of $4^{\circ} \mathrm{C}$ when stored for up to 4 weeks (Lightowlers et al. 1996). Viability control is essential for calculating the efficiency of the establishment of infection and must be performed for each experiment (Santamaria et al. 2002). Several authors have reported difficulties in infecting pigs experimentally (Aluja et al. 1996, Verastegui et al. 2000, Nguekam et al. 2003). According to Nguekam et al. (2003), the ingestion of whole proglotids is the most efficient means of infection, which suggests that there may be a factor in fecal matter and/or proglotids that enhances the infectivity of the eggs. The method also offers the advantage of mimicking the natural mode of infection (Deckers et al. 2008).

Tongue palpation is the only method of ante-mortem detection of infected pigs in the majority of developing countries where cyscticercosis is endemic. While the technique is very specific $(100 \%)$, it is not very sensitive when used on pigs with a low cyst burden (Sciutto et al. 1998, Boa et al. 2002, Phiri et al. 2006, Soares et al. 2006).

The present study confirms the low sensitivity of tongue palpation and routine meat inspection for cysticercosis diagnosis in pigs with low infection. Dorny et al. (2004) describe a similar finding and estimated the sensitivity of tongue examination and carcass inspection to be 21 and $22 \%$, respectively. Phiri et al. (2006) also found that pigs with a low parasite burden did not test positive through tongue examination and carcass inspection, as these methods failed to detect cysticercosis in $83 \%$ and $61 \%$ of the animals, respectively. In endemic areas, most commercialized pigs with light infection may escape from being detected by meat inspection and the consumption of undercooked pork meat is therefore a risk factor for infection.

Detailed necropsy was performed under laboratory conditions and was able to identify cysts in all pigs (Table 1). Muscles were carefully examined, leading to a recovery of a higher number of cysticercis found in comparison with routine meat inspection. Only $18.06 \%$ of the cysticercis were located in the heart, tongue and masseter, which are tissues and organs indicated for routine meat inspection for cysticercosis in Brazil. These results corroborate those described by Boa et al. (2002), who found that only $10.6 \%$ of metacestodes are present in muscles or organs indicated for the search of cysticercosis. As detailed necropsy of pig carcasses followed by the enumeration of cysticerci (considered here as the golden standard) is time-consuming and expensive, it is therefore impractical for traditional inspection and would lead to commercial losses (Gonzalez et al. 1990, Pinto et al. 2000).

Serological tests are more sensitive than the classic tongue examination, are relatively inexpensive and easy to perform on a large number of samples (Dorny et al. 2003). Studies have demonstrated the high specificity and sensitivity of the native $14 \mathrm{kDa}$ protein isolated from T. solium cysticerci using the ELISA (Michault et al. 1990, Greene et al. 2000, Obregon-Henao et al. 2001, Assana et al. 2007).

As shown in Figure 1, the level of IgG antibodies in some experimentally infected pigs increased after 21 days PI, with variations throughout the experimental period. Santamaria et al. (2002) and Sato et al. (2003) describe similar 
results, with the increase of antibody level occurring on the $30^{\text {th }}$ day PI. Ferrer et al. (2003) also report a clearly detectable antibody response to antigens in bovine cysticercosis, beginning at approximately two to three weeks post- infection. Our results corroborate these studies, demonstrating that anti-T. solium cysticerci antibodies can be detected by ELISA in the early stages of infection, even in light infections. The level of antibodies had no direct correlation with the number of cysticerci identified in the experimentally infected pigs, as an animal infected with only six parasites had high titers. Moreover, high antibody titers were determined in the sera of all the naturally heavily infected pigs.

Extensive studies have reported that the poor antigenicity of recombinant proteins could be explained by the absence or deficiency of glycosilation for proteins expressed in E. coli, which contributes for their immunogenicity (Sako et al. 2000, Obregón-Henao et al. 2001). Our results indicate that the absence of post-translational modifications did not change antigenicity or specificity for recombinant TS14.

The MoAb used in this paper was generated from TS14 recombinant antigens and previous experiments have suggested that TS14 is a subunit of larger disulfite-bonded antigens (Greene et al. 1999, Plancarte et. al. 1999, Hancock et al. 2003, Silva et al. 2006). Based on these results, we decided to use MoAb anti-Ts14 for the immunodiagnosis of porcine cysticercosis.

In the standardization of the method, the treatment of the sample with TCA and the first incubation of the treated sample with biotinylated MoAb-TS14 was found to increase the sensitivity of the test. The TCA treatment has been found to dissociate immuno-complexes in a number of studies (De Jonge et al. 1987, Draelants et al. 1995, Dorny et al. 2000, Nguekam et al. 2003).

The results obtained from the Ag-ELISA demonstrate that this test is not appropriate for pigs with low infection. For naturally heavily infected pigs, the test was successful with all animals due to the high infection rate. Similar results were reported by Nguekam et al. (2003), who found that the same happens with animals harboring small number of viable cysts $(<100)$. The sensitivity of the test drops from $92.3 \%$ to $12.8 \%$ when less than 50 cysticerci are present (Van Kerchoven et al. 1998, Dorny et al., 2000). According to Brandt et al. (1992), differences in the sensitivity of the test may be related to the permeability of the host capsule around the cysticercus, which influences the amount of excretory-secretory products released into the circulation.

\section{CONCLUSION}

Our experiment demonstrates once more that tongue examination and routine meat inspection are none indicated methods for the diagnosis of cysticercosis in slightly infected pigs. Ag-ELISA also failed as an identification method for slightly infected animals, whereas Ab-Elisa successfully identified pigs with a low burden of parasites. Recombinant TS14 together with the ELISA technology is a less expensive and simple diagnostic method and can be useful as a sero-epidemiological tool for porcine cysticercosis.
Acknowledgement.- The study was supported by a grant from Fundação de Amparo à Pesquisa do Estado de São Paulo (FAPESP, 2002/12061-0).

\section{REFERENCES}

Aluja A.S., Villalobos A.N.M., Plancarte A., Rodarte L.E., Hernadez M. \&.Siuto M. 1996. Experimental Taenia solium cysticercosis in pigs: Characteristics of the infection and antibody response. Vet. Parasitol. 61:4959.

Aluja A.S., Villalobos A.N.M., Plancarte A., Rodarte L.F., Hernadez M., Zamora C. \& Siuto M. 1999. Taenia solium cysticercosis: Immunity in pigs induced by primary infection. Vet. Parasitol. 81:129-135.

Assana E., Kanobana K., Tume C.B., Zoli P.A., Nguekam J.P., Geerts S., Berkevens D. \& Dorny P. 2007. Isolation of a $14 \mathrm{kDa}$ antigen from Taenia solium cyst fluid by HPLC and its evaluation in enzyme linked immunosorbent assay for diagnosis of porcine cysticercosis. Res. Vet. Sci. 82:370-376.

Brandt J.R.A., Geerts S. De, De Deken R.S., Kumae V., Ceulemans F., Brijs L. \& Fialla N. 1992. A monoclonal antibody-based ELISA for the detection of circulating excretory-secretory antigens in Taenia saginata cysticercosis. Int. J. Parasitol. 22:471-477.

Boa M.E., Kassuku A.A., Willingham III A.L., Keyyu J.D. \& Phiri I.K. 2002. Distribution and density of cysticerci of Taenia solium by muscle groups and organs in naturally infected local finished pigs in Tanzania. Vet. Parasitol. 106:155-164.

De Jonge N., Fillié Y.E. \& Deelder M.A. 1987. Simple and rapid treatment (trichloroacetic acid precipitation) of serum samples to prevent non-specific reactions in the immunoassay of proteoglycan. J. Immunol Meth. 99:195-197.

Deckers N., Kanobana K., Silva M.. Gonzalez A.E., Garcia H.H.,Gilman R.H. \& Dorny P. 2008. Serological responses in porcine cysticercosis: A link with the parasitological outcome of infection. Int. J. Parasitol. 38:11911198.

Dorny P., Vercammen F., Brandt J., Vansteenkiste W., Berkvens D. \& Geerts S. 2000. Sero-epidemiologica study of Taenia saginata cysticercosis in Belgian cattle. Vet. Parasitol. 88:43-49.

Dorny P., Phiri I., Gabriel S., Speybroeck N. \& Vercruysse J. 2002. Sero-epidemiological study of bovine cysticercosis in Zambia. Vet. Parasitol. 104:211-215.

Dorny P., Brandt J., Zoli A. \& Geerts S. 2003. Immunodiagnostic tools for human and porcine cysticercosis. Acta Trop. 87:79-86.

Dorny P., Phiri I.K., Vercruysse J., Gabriel S., Willingham A.L., Brandt J., Victor B., Speybroeck N. \& Berkvens D. 2004. Bayesian approach for estimating values for prevalence and diagnostic test characteristics of porcine cysticercosis. Int. J. Parasitol. 34:569-576.

Draelants E., Hofkens E., Harding E., Brandt J. \& Geerts S. 1995. Development of a DOT-ELISA for the detection of circulating antigen in cattle infected with Taenia saginata cysticerci. Res. Vet. Sci. 58:99-100.

Espíndola N.M., Vaz A.J., Pardini A.X. \& Fernandez I. 2002. Excretory/secretory antigens (ES) from in vitro cultures of Taenia crassiceps cysticercosis, and use of an anti-ES monoclonal antibody for antigen detection in samples of cerebrospinal fluid from patients with neurocysticercosis. Ann. Trop. Med. Parasitol. 96:361-368.

Ferrer E., Benitez L., Foster-Cuevas M., Bryce D. \& Wammae L.W. 2003. Taenia saginata derived synthetic peptides with potential for the diagnosis of bovine cysticercosis. Vet. Parasitol. 111:83-94.

Flisser A., Sarti E., Lightowlers M. \& Schantz, P. 2003. Neurocysticercosis: regional status, epidemiology, impact and control measures in the Americas. Acta Trop. 87:43-51.

Garcia H.H., Gonzalez A.E., Gilman R.H., Palacios L.G., Jimenez I., Rodrigues S., Verastegui M., Wilkins P \& Tsang V.C. 2001. Short report: transient antibody response in Taenia solium infection in field conditions: a major contributor to high seroprevalence. Am. J. Trop. Med. Hyg. 6:31-32.

Gonzales A.E., Cama V., Gilman R.H,. Tsang V.C., Pilcher J.B,.Chavera A., Castro M., Montenegro T., Verastegui M. \& Miranda E. 1990. Prevalence and comparison of serological necropsy, and tongue examination for the diagnosis of porcine cysticercosis in Peru. Am. J. Trop. Med. Hyg. 43:194199. 
Greene R.M., Wilkins P.P. \& Tsang V.C.W. 1999. Diagnostic glycoproteins of Taenia solium cysts share homologous 14 and 18 KDa subunits. Mol. Biochem. Parasitol.99:257-261.

Greene R.M., Hancock K., Wilkins P.P. \& Tsang V.C.W. 2000. Taenia solium: Molecular cloning and serologic evaluation of 14- and 18-kDa related, diagnostic antigens. J. Parasitol. 86:1001-1007.

Hancock K., Khan A., Williams F.B., Yushak M.L., Pattabhi S., Noh J. \& Tsang V.C.W. 2003. Characterization of the 8-Kilodalton antigens of Taenia solium metacestodes and evaluation of their use in an enzyme-linked immunosorbent assay for serodiagnosis. J. Clin. Microbiol. 41:2577-2586.

Handali S., Gonzalez A.E., Hancock K., Garcia H.H., Roberts., J.M ., Gilman R.H. \& Tsang V.C. 2004. Porcine antibody responses to Taenia solium antigens rGp50 and sTs18var1. Am. J. Trop. Med. Hyg.71:322-326.

Lightowlers M.W., Rolfe R. \& Gauci C.G. 1996. Taenia saginata: Vaccination against cysticercosis in cattle with recombinant oncosphere antigens. Exp. Parasitol. 84:330-338.

Michault A., Riviere B., Fressy P., Laporte J.P., Bertil G. \& Mignard C. 1990. Apport de L'enzyme-linked immunoeletrotransfer blot assay au diagnostic de la neurocysticercosis. Pathol. Biol. 38:119-125.

Michault A., Rivière B. \& Fressy P. 1990. Apport de l'enzyme-linked immunoeletrotransfer blot assay au diagnostic de la neurocysticercose humaine. Path. Biol. 38:119-125.

Nguekam A., Zoli A.P., Vondou L., Pouedet S.M.R., Assana E., Dorny P., Brandt J., Losson B. \& Geerts S. 2003. Kinetics of circulating antigens in pigs experimentally infected with Taenia solium eggs. Vet. Parasitol. 111:323-332.

Nunes C.M., Biondi G.F., Heinkemann M.B. \& Richtzenhain L.J. 2000. Comparative evaluation of an indirect ELISA test for diagnosis of swine cysticercosis employing antigen from Taenia solium and Taenia crassiceps metacestodes. Vet. Parasitol. 93:135-140.

Obregon-Henao A., Gil D.L., Gómez D.I., Sanzon F., Teale J.M. \& Restrepo B.I. 2001. The role of N-linked carbohydrates in the antigenicity of Taenia solium metacestode glycoproteins of 12,16 and $18 \mathrm{kD}$. Mol. Bioch. Parasitol. 114:209-215.

Pawlowski Z., Allan J. \& Sarti E. 2005. Control of Taenia solium taeniasis/ cysticercosis: From research towards implementation. Int. J. Parasitol. 35:1221-1232.

Phiri I.K., Dorny P., Gabriel S. Willian A L., Sikasungel C., Siziyas S. \& Vercruysse J.2006. Assessment of routine inspection methods for porcine cysticercosis in Zambian village pigs. J. Helminthol. 80:69-72.

Pinto P.S.A., Vaz A.J., Germano P.M.L. \& Nakamura P.M. 2000. ELISA test for diagnosis of cysticercosis in pigs using antigens of Taenia solium and Taenia crassiceps cysticerci. Revta Inst. Med. Trop. São Paulo 42:71-79.

Plancarte A., Hirota C., Martinez_Ocana J., Mendoza-Hernandez G., Zente- no E. \& Flisser A.1999. Characterization of GP39-42 and GP24 antigens from Taenia solium cysticerci and of their antigenic GP10 subunit. Parasitol. Res. 85:680-684.

Román G., Sotelo J., Del Bruto O., Flisser A., Dumas M., Wadia N., Botero D., Cruz M., Garcia H., De -Bitenccourt P.R Trelles L., Arriagada C., Lorenzana P., Nash T.E. \& Spina-França A. 2000. A proposal to declare neurocysticercosis an international reportable disease. Bull. WHO 78(3):399-406.

Sakai H., Barbosa J.V., Silva E.M. , Schlabitz F.O., Noronha R.P., Nonaka N., Franke C.R. \& Ueno H. 2001. Short report: Seroprevalence of Taenia solium cysticercosis in pigs in Bahia state, northeastern Brazil. Am. J. Trop. Med. Hyg. 64:268-269.

Sako Y., Nakao M., Ikejima T., Piao Z.X., Nakaya K. \& Ito A. 2000. Molecular characterization and diagnostic value of Taenia solium low-molecular-weight antigen genes. J. Clin. Microbiol. 38:4439-4444.

Santamaria E., Plancarte A. \& Aluja A.S. 2002. The experimental infection of pigs with different numbers of Taenia solium eggs: Immune response and efficiency of establishment. J. Parasitol. 88:69-73.

Sato M.O., Yamasaki H., Sako Y., Nakao M., Nakaya K., Plancarte A., Kassuku A.A., Dorny P., Geerts S., Benitez-Ortiz W., Hashiguchi Y. \& Ito A. 2003. Evaluation of tongue inspection and serology for diagnosis of Taenia solium cysticercosis in swine: Usefulness of ELISA using purified glycoproteins and recombinant antigen. Vet. Parasitol. 111:309-322.

Sciutto E., Hernández M., De Garcia G., Aluja A.S., Villalobos A.N.M., Rodarte L.F., Parkhouse M. \& Harrison L.1998. Diagnosis of porcine cysticercosis: A comparative study of serological tests for detection of circulating antibody and viable parasites. Vet. Parasitol. 78:185-194.

Silva M.R.M., Maia A.A.M., Espíndola N.M., Machado L.R.,Vaz A.J. \& Henrique-Silva F. 2006. Recombinant Expression of Taenia solium TS14 antigen and its utilization for immunodiagnosis of neurocysticercosis. Acta Trop. 100:192-198.

Soares K.A., Silva M.R.M., Poleti M.D. \& Maia A.A.M. 2006. Imunodiagnóstico da cisticercose em suíno experimentalmente infectado com ovos de Taenia solium, utilizando antígeno de escólex de Cysticercus cellulosae. Arq. Bras. Med. Vet. Zootec. 58:15-20.

Van Kerckhoven I., Vansteenkiste W., Claes M., Geerts S. \& Brandt J. 1998. Improved detection of circulanting antigen in cattle infected with Taenia saginata metacestodes. Vet. Parasitol. 76:269-274.

Verastegui M., Gonzalez A., Gilman R.H., Gaviria C., Falcon N., Bernal T. \& Garcia H.H. 2000. Experimental infection model for Taenia solium cysticercosis in swine. Vet. Parasitol. 94:33-44.

Tsang V.C., Pilcher A.J., Zhow W., Boyer E.A. \& Kamangoman I.P.E.1991. Efficacy of the immunoblot assay for cysticercosis in pigs and modulated expression of distinct IgM/IgG activities to Taenia solium antigens in experimental infection. Vet. Immunol. Immunopathol. 29:69-78. 